学術論文

\title{
無方向性電磁鋼板の磁場中熱処理効果の評価
}

\section{Heat Treatment in Magnetic Field for Non-oriented Electrical Steel Sheet}

\author{
木下 創”1(正員)，戸高 孝*2(正員)，佐藤 尊*2(正員)，下地 広泰*3(正員)
}

Tsukuru KINOSHITA (Mem.), Takashi TODAKA (Mem.), Takeru SATO (Mem.), Hiroyasu SHIMOJI (Mem.)

Heat treatment of non-oriented electrical steel sheets is performed in a magnetic field in order to control microstructure orientation and magnetic characterization. Magnetic field (0.5T-5T) is applied to specimens in a direction parallel to the rolling direction during heat temperature from $1023 \mathrm{~K}$ to $1123 \mathrm{~K}$. Specimens magnetically heat treated, showed anisotropic characterization due to crystallographic orientation under high magnetic exciting condition. Recrystallization texture and orientation of specimens are characterized with X ray pole figure analysis. Magnetic heat treatment is found to enhance the selection of (100) or (110) plate parallel to electrical steel sheet surface.

Keywords: Heat treatment, iron loss, crystallographic orientation, anisotropy, pole figure

(2016 年 11 月 24 日受付, 2017 年 4 月 20 日再受付)

\section{1 緒言}

国際的なエネルギーの有効活用に対する要求があ り，とりわけ電力消費全体に対する割合の大きい回転 電動機(以下電動機と記す)に対して小型・高効率化が 求められている。電動機の効率は, IEC 規格で規定さ れており, 効率クラスとして IE1(標準効率)から IE3(プ レミアム効率)まで定められている。2015 年より IE3 に準じたトップランナ一制度が適用されたことから， 電動機の高効率化の要求が高まっていくものと考えら れる。

これらの社会的背景を踏まえ電動機の高効率化一 の取組みとして，損失の主要因である鉄損の低減が挙 げられる。鉄損は鉄心の加工時の残留応力の影響で増 大し磁気特性は劣化することが知られており，鉄心材 料の変更を伴わないで鉄損を低減するためには製造時 に付与される残留応力の低減または, 活用が必要であ ると考えられる。

残留応力の低減については歪取り焼鈍が有効とさ れており，無方向性電磁鋼板においては約 $750^{\circ} \mathrm{C} の$ 熱 処理により加工歪による磁気特性の劣化を抑制するこ とが可能とされている[1]。しかしながら，歪取り燒鈍

\footnotetext{
連絡先：木下 創, $\bar{\top} 237-8555$ 神奈川県横須賀市夏島町 19 番地, 住友重機械工業(株) 技術研究所,

e-mail: tsukuru.kinoshita@shi-g.com

*1住友重機械工業 *2 大分大学

*3 大分県産業科学技術センター
}

を行う事により，素材の集合組織が変化し磁化困難軸 を含む組織が電磁鋼板の面内に発現し，結晶磁気異方 性が発現するとされる $1.5 \mathrm{~T}$ 以上において磁気特性が 劣化することが報告されるなど，単純な熱処理プロセ スでは素材の特性を十分に活用できないことが懸念さ れる $[2,3]$ 。そこで，本論文では熱処理中に磁性材料の 集合組織の制御が可能であると考えられる磁場中熱処 理に着目した。

磁性材料を磁場中で熱処理することにより磁気特 性が向上することは古くから知られており [4]，その集 合組織が制御可能であることは報告されている $[5,6]$ 。 しかし, 磁場中熱処理された無方向性電磁鋼板の交番 励磁下における磁気特性に関する詳細な報告は少ない。 従って, 本論文では温度一磁場条件による交番励磁下 での磁気特性および，電磁鋼板の集合組織について検 討を行った。

\section{2 実験方法}

\section{1 磁場中熱処理装置}

磁場中熱処理装置は内径 $100 \mathrm{~mm}$ を有する超電導マ グネット(10T-CSM) と外径 50mm, 内径 $22 \mathrm{~mm}$ の電気 炉を内に外径 $14 \mathrm{~mm}$, 内径 $12 \mathrm{~mm}$ の石英ガラス管の一 端を閉じたものを挿入し, ターボ分子ポンプで $10^{-3}[\mathrm{~Pa}]$ 以下に減圧可能な構造となっている[7]。

試料は無方向性電磁鋼板 50A470(JIS C 2552)をワイ 
ヤ放電加工により $10 \mathrm{~mm} \times 10 \mathrm{~mm}$ に切断し, 石英で製作 した保持治具を用いて磁場中心に磁場方向と圧延方向 が平行になるように石英管内に設置し, 試料位置にお ける熱処理中の磁場の均一性は十分に確保されている。 試料付近の温度は Pt-Rh 熱電対を用いて測定した。

Fig.1 に温度プロファイルと磁場印加パターンを示 す。本試験では $T / t_{1}=500^{\circ} \mathrm{C} / \mathrm{hr}$ で設定温度まで昇温し, 目標温度到達後 $\left(t_{2}-t_{1}\right)=1 \mathrm{hr}$ を温度の保持時間とし, その 後 $T /\left(t_{3}-t_{2}\right)=100^{\circ} \mathrm{C} / \mathrm{hr}$ で室温まで降温する。磁場は目標 温度到達時から印加を始め一定磁場を保持したまま室 温まで印加を続けた。

Table1 に本試験の処理条件を記す。到達設定温度は $T=750^{\circ} \mathrm{C}, 850^{\circ} \mathrm{C}$ と, 磁場の大きさは $\mathrm{B}=0 \mathrm{~T} \sim 5 \mathrm{~T}$ とし た。

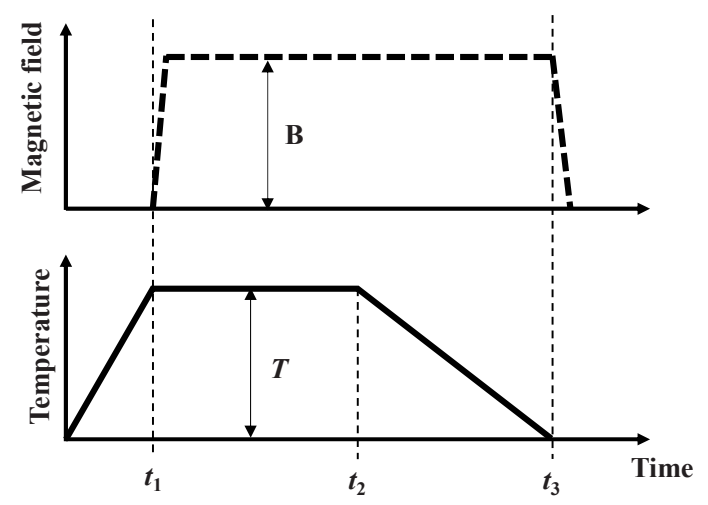

Fig. 1 Schematic diagram of heat treatment condition in magnetic field.

Table1 Production condition of the samples.

\begin{tabular}{ccc}
\hline Sample name & Temperature $\left[^{\circ} \mathrm{C}\right]$ & $\begin{array}{c}\text { Applied magneti } \\
\text { field }[\mathrm{T}]\end{array}$ \\
\hline \hline NO & - & - \\
0T-750 & 750 & 0 \\
0.5T-750 & 750 & 0.5 \\
1.0T-750 & 750 & 1.0 \\
2.0T-750 & 750 & 2.0 \\
5.0T-750 & 750 & 5.0 \\
2.0T-850 & 850 & 2.0 \\
5.0T-850 & 850 & 5.0 \\
\hline
\end{tabular}

\subsection{2 次元磁気特性測定 $[8]$}

Fig. 2 に 2 次元磁気特性測定装置を示寸。 2 次元磁気

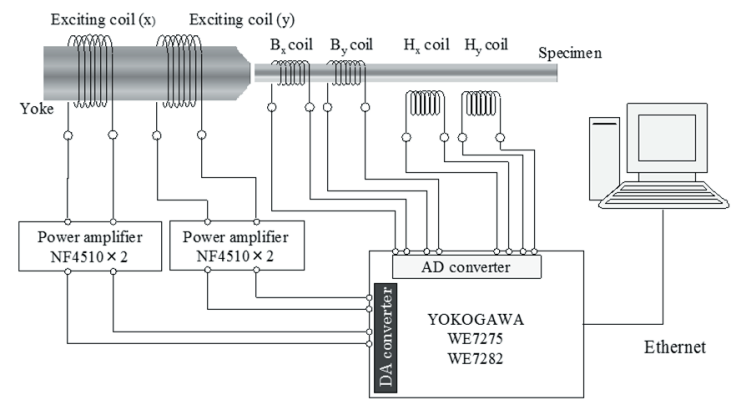

(a) Measurement systems

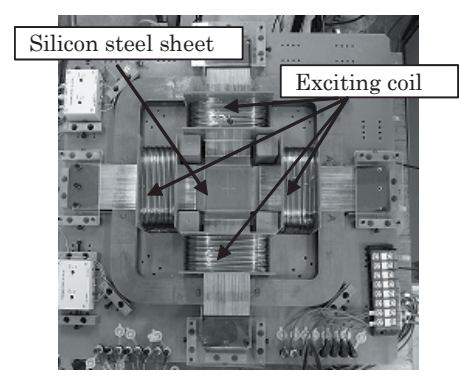

(b) Main system
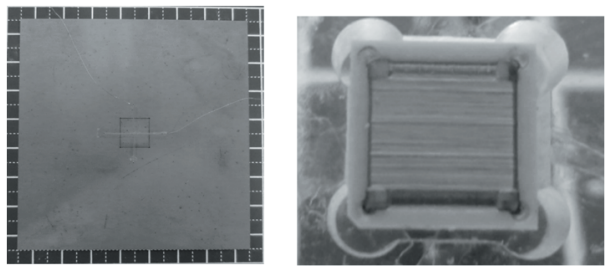

(c) Electrical steel sheet

(d) H-coil

Fig. 2 Two-dimensional magnetic measurement apparatus.

特性測定装置は中心部に置かれた試料に対し任意方向 の交番磁束で励磁し磁気特性を測定する。Fig.2(a)示す ように，任意方向の交番磁束密度を測定試料に励磁す るためにフィードバック制御が可能なシステムになつ ている。Fig.2(c)に示すように B コイルは各 $\mathrm{x}, \mathrm{y}$ 方向 に巻かれており, 磁束密度 $\boldsymbol{B}$ は $B_{x}, B_{y}$ として検出され る。また, Fig.2(d)に示すように磁界強度 $\boldsymbol{H}$ は $\mathrm{x}$ 方向, $\mathrm{y}$ 方向に十字に巻かれた $\mathrm{H}$ コイルによって $H_{x}, H_{y}$ とし て測定される。B コイルと $\mathrm{H}$ コイルの位置関係は B コ

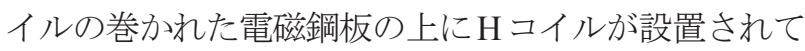
いる。Fig.2(c)に示すようにB B イルは励磁用電磁鋼板 の中心 $20 \mathrm{~mm} \times 20 \mathrm{~mm}$ の範囲に巻かれており，励磁用 電磁鋼板の中心部に $10 \mathrm{~mm} \square$ の穴を設けてそこに試料 を設置する。励磁用電磁鋼板は熱処理試料と同ロット の鋼板から製作されており面一性は確保されている。 磁界強度 $\boldsymbol{H}$ は, 試料中心部直上に試料の圧延方向と $\mathrm{x}$ 
方向が平行になるように設置された $4 \mathrm{~mm} \times 4 \mathrm{~mm}$ の $\mathrm{H}$ コイルで測定される。任意方向の交番磁束密度を試料 に励磁するため, 励磁コイルにおいてもそれぞれ $\mathrm{x}$ 方 向, $\mathrm{y}$ 方向の 2 方向から励磁できるように設置されて いる。また, 積層されたヨークを使うことによって磁 束の漏れを防ぎ渦電流の発生を少なくしている。本測 定装置を用いて中央部の試料を含む $20 \mathrm{~mm} \times 20 \mathrm{~mm}$ の領 域の磁束密度が正弦波に制御された条件の基, 任意方 向の磁気特性の測定を行う。以上の条件を基に同一条 件の試料を 3 個製作し, その平均值を測定結果とした。

\section{$2.3 \mathrm{X}$ 線回折測定}

磁場中熱処理試料の集合組織を評価するためにX 線 極点図測定を行った。極点図測定を行うに当たり，事 前に主要な $X$ 線回折ピークを確認するために $\theta-2 \theta$ 測 定によって検出確認を行った。Fig.3に $\theta-2 \theta$ 測定結果 を示す。低角の回折角度加順に $\{110\},\{200\},\{211\}$ の比較的強度が大きいピークが得られることが判る。 $\{110\}$ と\{200\}は磁化容易軸方向である<100>を含むた め磁気特性を良好にせしめる重要な要因であると考え られる。\{211\}は磁化困難軸方向である<111>を含む結 晶面であることから磁気特性を悪化させる要因となり うる。本論文では磁気特性に対して効果があると考え られる上記 $3 つ の$ 回折ピークについて極点図測定を行 う事とし，これらの集合組織を効果的に制御すること ができる条件について検討する。また，X線極点図測 定で用いる回折角度は純鉄 $(\alpha-\mathrm{Fe})$ の值を使用し, 試料 毎の調整は行っていない。

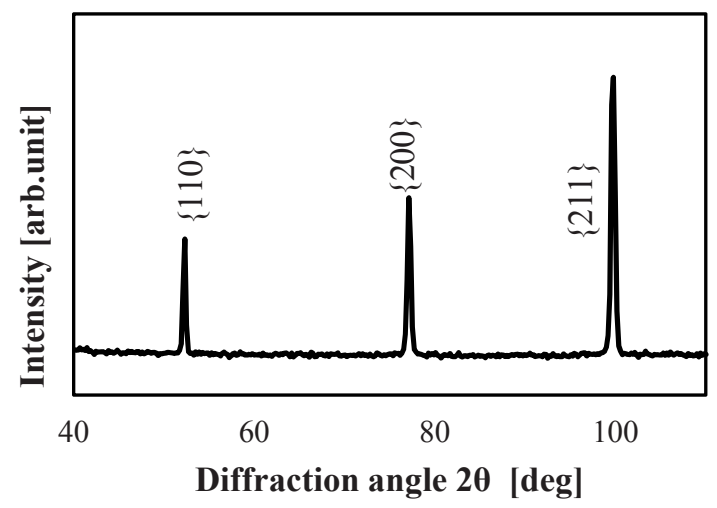

Fig. $3 \mathrm{X}$ ray diffraction pattern of non-oriented electrical steel sheet.

\section{3 結果と考察}

\subsection{2 次元磁気特性測定結果}

Fig.4 に各磁場中熱処理条件における圧延方向の磁 束密度と鉄損の関係を示す。熱処理前と比較すると一 定の鉄損の低減ができていることが確認できる。これ は試料の切り出し成形時の加工歪が歪取り焼鈍効果に より低減されたことによると考えられる。従って，本 測定システムによる定性的な磁気特性の評価が可能で あることが確認できた。また，圧延方向の磁気特性に 対する磁場の強度の影響を見ると $5 \mathrm{~T}$ までの磁場条件 であれば磁気特性に対してほとんど影響を及ぼさない ことが判った。

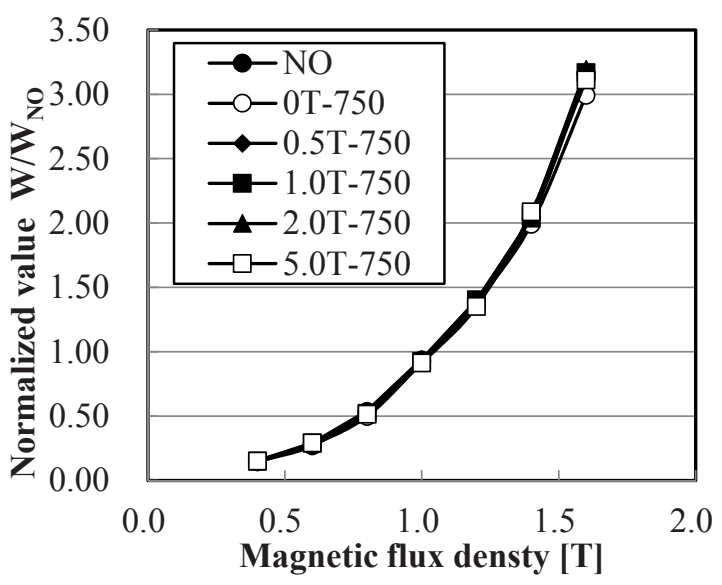

Fig. 4 Iron loss properties of magnetically heat treated samples.

次に交番励磁の磁場方向を変化させたときの磁気 特性を Fig.5 に示す。Fig.5(a)に示すように励磁条件 0.4T とするとすべての磁場中熱処理条件で鉄損が低 減することが分かる。これは上述の歪取り効果の影響 と考えられる。また, 圧延方向(0度)加ら圧延直交方 向(90 度)に向からに従って鉄損が増加しており, 圧延 磁気異方性が現れていると考えられる。Fig.5(b)では 励磁条件を $1.0 \mathrm{~T}$ としたときの各方向に励磁した鉄損 特性を示している。熱処理前の試料では前述の $0.4 \mathrm{~T}$ の時と同様に 0 度から 90 度に向からに従い鉄損が増 加している。一方, 熱処理後の試料は磁場の有無に関 わらず 45 度から 60 度で極值が観測されることから熱 処理により圧延異方性の効果が軽減され, 結晶異方性 が発現していている状態であると考えられる。さらに 励磁磁場の強度を大きくし 1.6T で測定した結果を

Fig.5(c)に示す。 


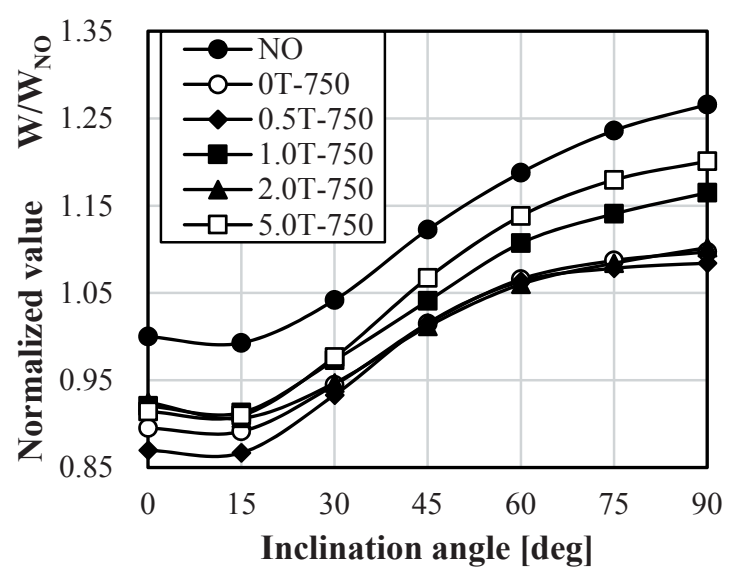

(a) $0.4 \mathrm{~T}$

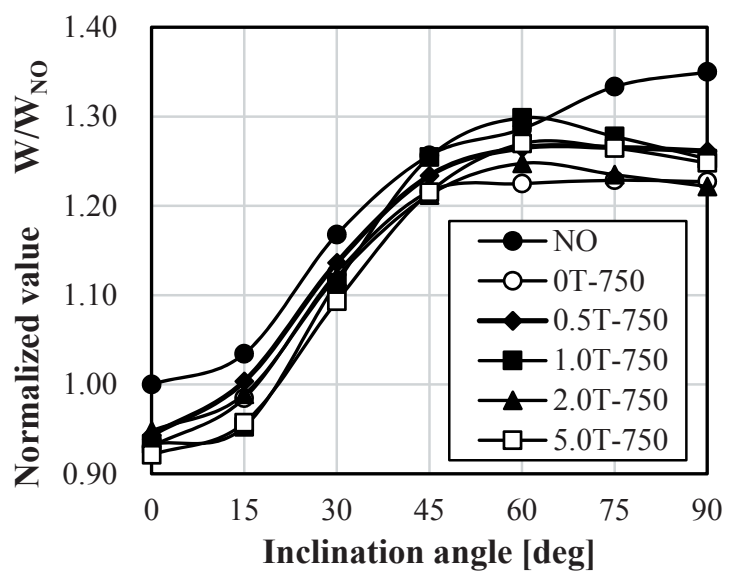

(b) $1.0 \mathrm{~T}$

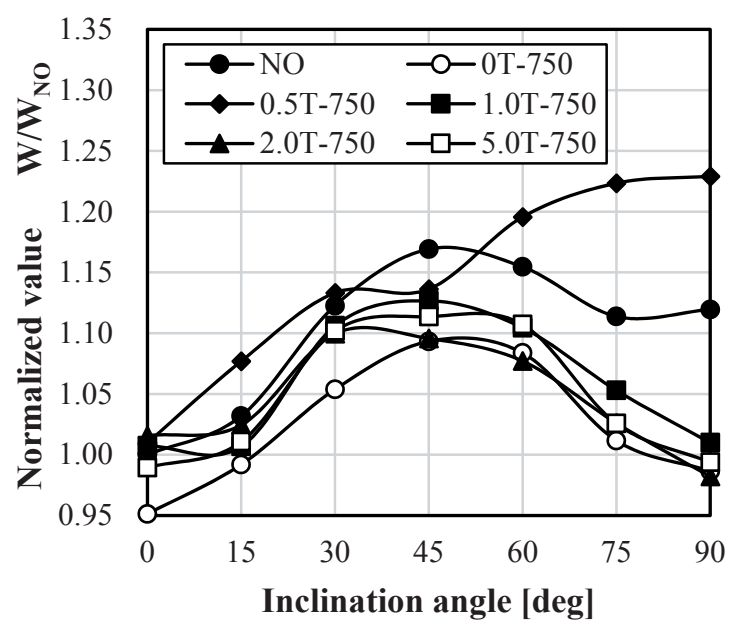

(c) $1.6 \mathrm{~T}$

Fig. 5 Depending on inclination flux angle of iron loss.

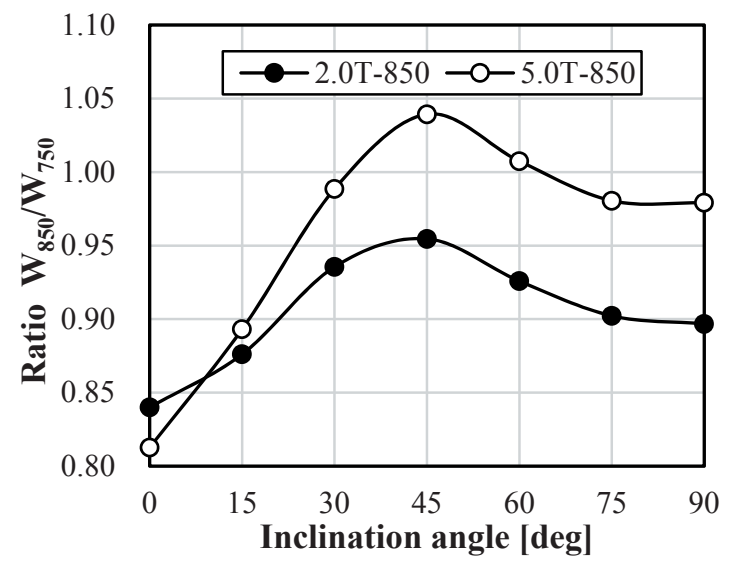

Fig. 6 Comparison of iron loss characteristics by heat treatment in magnetic field at $1123 \mathrm{~K}$.

0.5T-750 以外の全ての条件で 45 度付近の鉄損が最大 になり磁気異方性を有していることが分かる。磁気異 方性を示した試料の内 $0.5 \mathrm{~T}-750$ 以外は 0 度と 90 度の 鉄損值がほぼ等価であることから磁化容易軸である $<100>$ が 0 度に集積しそれと等価な $<010>$ が 90 度に向 いていると推定される。0.5T-750 では 0 度のよりも 90 度の鉄損が大きくなっており $\{110\}<001>$ が 0 度方 向に集合組織として存在する可能性を示している。

次に熱処理時の温度条件について検討を行った。

Fig.6に熱処理時の印加磁場 $2 \mathrm{~T}$ と $5 \mathrm{~T}$ につい $850^{\circ} \mathrm{C} て ゙$ 熱処理を行った試料の励磁方向による鉄損の変化を示 す。 $750^{\circ} \mathrm{C}$ で磁場中熱処理した試料の各励磁方向で規格 化し，励磁条件は 1.0T である。これより，5T-850の 45 度及び 60 度方向以外の磁気特性は処理温度 $750^{\circ} \mathrm{C}$ に比 べて低減しており，2T 以下の磁場中熱処理であれば印 加磁場より温度の方がより磁気特性に対する感度が高 いことがわかる。5T-850の 45 度，60 度では磁場中熱 処理による結晶異方性の影響が顕著に得られた結果で あると考えられる。従って, より大きな磁場, または 温度等高いエネルギー状態を作り出すことでより磁気 特性に影響を与えることができる可能性を示している。

\section{3. $2 \mathrm{X}$ 線回折測定結果}

Fig.7(a) に熱処理試料と同じ形状に切り出した熱処 理前の電磁鋼板の $X$ 線極点図測定結果を示す。 $\{110\}$ 極点が極点図の中心(試料の鉛直方向:ND)に対して約 


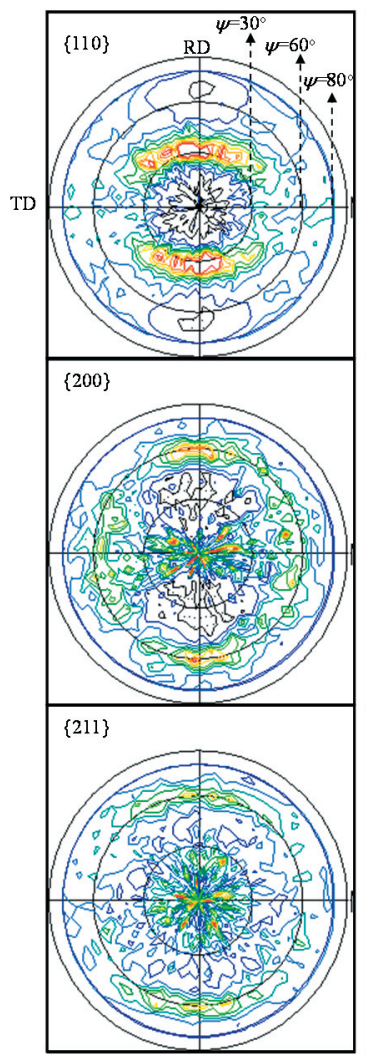

(a) $\mathrm{NO}$

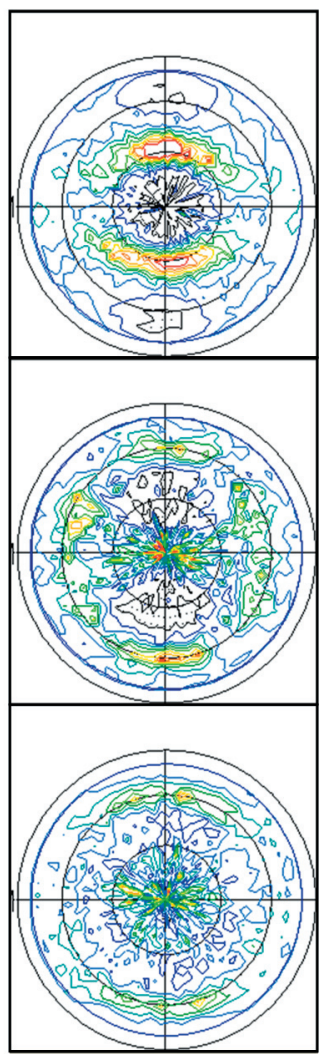

(b) $0 \mathrm{~T}-750$

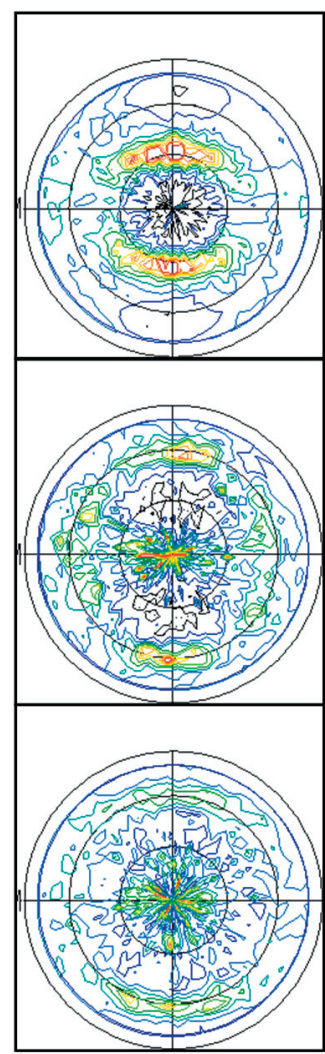

(c) $5 \mathrm{~T}-750$

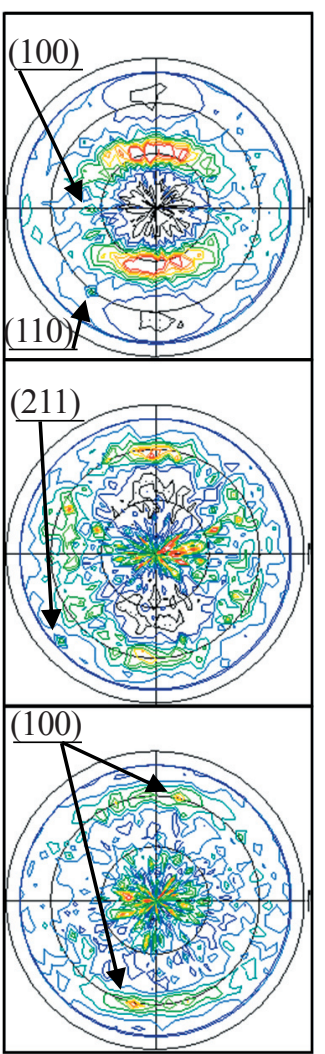

Contours color of intensity

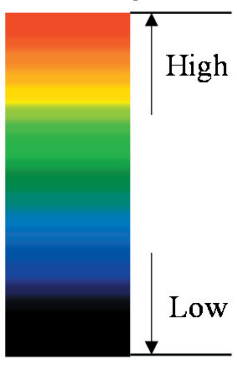

(d) $5 \mathrm{~T}-850$

Fig. $7\{110\},\{200\},\{211\}$ pole figure analysis of magnetically heat treated non-oriented electrical steel sheet.

$35^{\circ}$ 圧延方向(RD)に傾いた位置に存在し，また，\{200\} 極点が RD に約 $60^{\circ}$ 傾き， $0^{\circ} ， 60^{\circ} ， 120^{\circ}$ 鋼板面に回転 した位置に存在することから鋼板面に平行に(111)面 に近い集合組織を有していることが判る。また，\{211\} 極点においては NDに付近に強度の大きい極点が点在 しており，(112)，(122)面に近い集合組織を鋼板面に平 行に有していることが判る。従って, $\{110\},\{200\}$ 極点 図測定の結果と併せると試料表面に平行に(111), (112), (122)面と比較的磁化困難軸方向 $<111>$ を含夕やすい面 指数を有する集合組織が存在することが判る。

Table2 に熱処理条件による各極点図測定で得られた X線回折強度を示す。磁場を印加しない状態での熱処 理では, 熱処理前の試料と比較すると $\{110\}$ 極点と $\{211\}$ 極点でその差が確認された。\{110\}極点では最大 の強度が得られる $\mathrm{RD}$ 方向に約 35 度傾いた位置の強 度が低下していることが確認できることから，(111)面 が減少していることがわかる。Fig.7(b)に示寸 $\{211\}$ 極 点においては ND 付近の強度が低下し，(112)面が減少 していることが分かった。磁化困難軸方向 $<111>$ を含 む面である(211)面主体の集合組織が低減できたこと から磁気特性を改善する方向に向かうことが予想され，
上述の磁気特性の測定結果でも磁気特性の改善傾向が 得られている。

次に, 熱処理時の磁場が集合組織に与える影響につ いて検討を行った。Table2 に示すように温度条件 $750^{\circ} \mathrm{C}$ では $0.5 \mathrm{~T}$ 以上の磁場中熱処理条件においてすべての 条件で $\{200\},\{211\}$ 極点図測定結果で変化が得られた。 $\{200\}$ 極点図では ND 付近の強度が減少していること から(100)面が減少していることが判る。また, Fig.7(c) に示すように傾き角が約 $40^{\circ}$ から $60^{\circ}$ で集合組織が観 測されている。特に RD と TD で比較的高強度の極点 が得られていることから(110)面，または(111)面に近い 集合組織が鋼板面に平行に増加したと考えられる。 $\{211\}$ 極点については磁場により $\mathrm{RD} に 60^{\circ}$ 傾けた位置 の強度が低下していることから(111)面が減少したと 考えられる。従って\{200\}極点図で観測された集合組織 は(110)面に近い面を主体とした集合組織であると考 えられる。

磁場中熱処理時の温度条件を $850^{\circ} \mathrm{C}$ とて集合組織 の変化を観察した結果を Fig.7(d)に示す。 $850^{\circ} \mathrm{C}$ では $\{200\}$ 極点において, 傾き角約 $40^{\circ}$ から $60^{\circ}$ の強度が減 少したことから（111）面が減少したと考えられる。ま 
Table $2 X$ ray diffraction intensity of $\{110\},\{200\}$ and $\{211\}$ pole figures.

\begin{tabular}{cccc}
\hline Sample name & $\{110\}$ & $\{200\}$ & $\{211\}$ \\
\hline \hline NO & 5.5 & 11.3 & 5.3 \\
0T-750 & 5.0 & 11.2 & 4.5 \\
0.5T-750 & 4.0 & 5.4 & 6.4 \\
1.0T-750 & 3.9 & 5.2 & 5.1 \\
2.0T-750 & 4.8 & 5.0 & 7.7 \\
5.0T-750 & 4.6 & 6.0 & 5.5 \\
$2.0 T-850$ & 5.3 & 13.0 & 9.6 \\
$5.0 T-850$ & 4.6 & 8.4 & 9.9 \\
\hline
\end{tabular}

た, Table2 に示すように $750^{\circ} \mathrm{C} の$ 磁場中熱処理条件と 比較すると ND の\{200\}極点の強度が約 5 から約 8 13 まで増加していることから鋼板面に平行な(110)面と (111)面が減少し(100)面が主体となる集合組織に変質 したと考えられる。(100)面は磁化容易軸方向 $<100>$ を 含む面であることから, 鋼板面に平行な(100)面が増加 したことで磁気特性の改善効果が得られたと考えられ る。45 度方向の交番励磁よりも 0 度, 90 度の磁気特性 が良好であった理由についても(100)面の<001>を含む 集合組織が面内に平行に存在するため, 磁化容易軸が $\mathrm{RD}$ と TD に優先的に配向していたためであると説明 できる。磁気特性の測定結果では 5T-850 では RD 方向 に(110)<001>を主体とした集合組織の存在を予想させ たが，予想に則した結果は確認できなかった。温度条

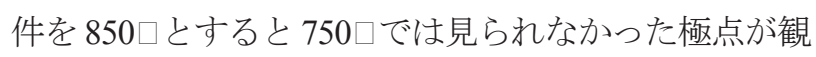
測されるようになり, 高温条件で磁場がより効果的に 作用すると考えられる。

\section{4 結言}

本論文では, 磁場中熱処理が無方向性電磁鋼板の磁 気特性に与える影響を交番励磁下による鉄損測定と X 線回折測定による集合組織の評価の観点から検討を行 い以下の知見を得た。

・ 熱処理中に磁場を印加することで電磁鋼板の集合 組織が変化し，熱処理前の(111)を主体とした鋼板 面に平行な集合組織から(100)が主体となる集合 組織に変化する。

- 交番励磁条件が $1.6 \mathrm{~T}$ のとき印加磁場 2.0T 以下で の磁場中熱処理では (100)面を主体とする集合組 織への変質に起因する鉄損特性の変化が得られ,
$\mathrm{RD}$ と TD の鉄損特性がほぼ等価になるが, 印加磁 場を $5 \mathrm{~T}$ とすると(110)の効果で $\mathrm{RD}$ 方向の鉄損が TD に比べ減少する。

・熱処理中の磁場強度が $5 \mathrm{~T}$ 以下であれば, 磁気特 性に対しては磁場強度条件に比べて温度条件の影 響の方が大きい。

以上より，磁場中熱処理により無方向性電磁鋼板の 集合組織を制御し，交番励磁下の磁気特性の大幅な改 良を試みたが，軽微な磁気特性の向上しか確認できな かった。一方，鋼板面に平行な集合組織の部分的な制 御が可能であることが確認できたことにより，磁場中 熱処理による磁気特性の向上の可能性を示すことがで きた。今後の課題として, 交番励磁下での定量評価と 磁場中熱処理の $10 \mathrm{~T}$ 程度までの高磁場化が挙げられる。

\section{謝辞}

本論文中の磁場中熱処理試料は東北大学金属材料研 究所附属強磁場超伝導材料研究センターの共同利用研 究（課題番号 16H0066）の成果を受けたものである。 試料製作に当たり多大な助言を頂いた高橋弘紀助教の 研究協力に謝意を表する。

\section{参考文献}

[1] JFE スチール(株), JFE の電磁鋼帯, 2010.

[2] A. Kutsukake, Y. Kido, T. Ikeda, T. Kinoshita, T. Todaka., "Influence of processing method of single sheet specimen on magnetic properties (No.4)", The Papers of Technical Meeting on Magnetics, IEE Japan, MAG-16-086, pp.23-28, 2016.

[3] M. Wada,'Improvement of Magnetic Characteristics of Laminations by Flash Annealing", National Technical Report, vol.50, no.6, pp.878-882, 1984.

[4] 小柴, 重本, 西沼, 原田, 異方性珪素鋼板の磁場中冷却 処理について, 日立評論「金属特集号 第 2 集」, 別冊第 16 号, 1956.

[5] N. Masahashi, M. Matsuo, K. Watanabe, J Mater Res, 1998.

[6] C.M.B. Bacaltchuk et al., Scripta Materialia, vol.48, pp. 13431347, 2003.

[7] 保科, 原川, 白石, 高橋, 小山, 磁場中熱処理によるケイ 素鋼の磁化方向の制御，ケーヒン技報，vol.2，pp.16-20， 2013.

[8] 佐藤, 榎園, 積分型ダイナミック E\&S モデルにおける B$\mathrm{H}$ 間の位相補正, 第 23 回 MAGDA コンファレンス論文 集, pp. 259-264, 2014. 